\title{
Uneven development and the commercialisation of public utilities: a political ecology analysis of water reforms in Malaysia
}

\author{
Rory Padfield ${ }^{\mathrm{a}}$, Mun Hou Tham ${ }^{\mathrm{a}}$, Sophie Costes ${ }^{\mathrm{b}}$, Laurence Smith ${ }^{\mathrm{b}}$ \\ ${ }^{a}$ Malaysia Japan International Institute for Technology, Universiti Teknologi Malaysia, Kuala \\ Lumpur, 54100, Malaysia \\ ${ }^{\mathrm{b}}$ SOAS, University of London, Thornhaugh Street, Russell Square, London, WC1H 0XG, UK
}

\author{
Article history: \\ Received 22 June 2015 \\ Received in revised form 5 February 2016 \\ Accepted 5 February 2016 \\ Available online February 2016 \\ http://dx.doi.org/10.1016/j.jup.2016.02.003 \\ 0957-1787/@ 2016 Elsevier Ltd. All rights reserved.
}

\section{Abstract}

Water policy reforms introduced in Peninsular Malaysia have yielded relatively positive improvements in the operational and financial performance of water utilities. This article analyses contemporary water governance in the context of the historical origins of uneven water development in Malaysia and national heterogeneity in the political economy of water provision. The investigation builds on political ecology scholarship in urban water policy and reaffirms postcolonial critiques of neoliberal inspired water reforms in developing countries. Our study analyses the impact of the 'asset light policy' - a policy introduced in 2008 with the aim of commercialising public water utilities and centralising water sector investment and ownership. It is found that notwithstanding evidence of improved financial health and technical efficiency in certain states, the asset light policy has accentuated uneven water development across the country. Thus despite the policy's relatively narrow focus on technical and financial matters, it is shown to have a fundamentally political outcome. This in turn explains the current 'policy impasse' in five of the eleven states in Peninsular Malaysia. Furthermore, the omission of environmental considerations within the policy framework is argued to undermine the overall ambition of the policy. It is recommended that water policy makers give greater consideration to the embedded social, political and economic inequalities that characterize many former European colonies.

Keywords: water policy, governance, Malaysia, commercialisation, political ecology, postcolonial

\section{Introduction}

This paper presents the findings of empirical research undertaken between 2012 and 2014 on the effects of neoliberal-inspired ${ }^{1}$ water policy reforms in Peninsular Malaysia. It argues that despite evidence in certain states of enhanced professionalism on the part of water utilities and improved financial and technical efficiencies following the implementation of the reforms, overall the policy has widened the gap between the high and low performing utilities. This finding is linked to three factors: first, the historically uneven development of water in Malaysia; second, the heterogeneity of

\footnotetext{
${ }^{1}$ Neoliberalism is defined as an economic and political ideology favouring free trade, privatisation and minimal government intervention (Collins English Dictionary, 2003: 1092). Practical manifestation of neoliberal water policies include the involvement of the private sector, the introduction of user charges, and strategies to manage demand for water, such as water meters and disconnection policies. Since the 1980s, neoliberal water policies have been advocated by leading international financial institutions, such as the World Bank, as well as policy makers - including those in the developing world - as a solution to the finance and management of water supply infrastructure (Goldman, 2005).
} 
the political economy of water provision across the country; and third, the prospect of fundamental changes to the political landscape of water governance brought about by the policy. In addition, it is also argued that the omission of broader environmental considerations within the policy is found to be a major limitation which undermines the overall ambition of the reforms.

This investigation of recent changes to water policy in Peninsular Malaysia adds to political ecology scholarship and contributes to postcolonial critiques of neoliberal inspired water reforms in developing countries. Once described as having 'a water supply system and a standard of technical service second to none in the colonial Empire' (Malaya Public Works Department [PWD], 1939, cited in; JBA 2012), Malaysia is a fitting site of investigation for three principle reasons. Firstly, under British colonial rule water supply systems were constructed across various parts of the Malaya Peninsular (Peninsular Malaysia) and Borneo territories (East Malaysia) to support Britain's strategic and resource extraction ambitions (MWA, 2005; Tajuddin, 2012; Wiryomartono, 2013). Considering the significant role played by British colonialists in determining the sites and extent of urban infrastructure, including water supply systems (Prasad, 2007; Tajuddin, 2012), it is pertinent to investigate the legacies of this period in shaping modern day water sector development.

Secondly, Malaysia's recent water development is characterised by a direct engagement with neoliberal philosophies of water supply provision. Following a failed water privatisation reform in the 1980s and 1990s (Tan, 2012), in 2006 Malaysia embarked on a policy solution - referred to as the 'asset light policy' - that aimed to transform the sector into one more compatible with neoliberal water provision. The asset light policy involves the commercialisation of state water utilities and the centralisation of water asset ownership and investment (Chin, 2008).

Thirdly, the make-up of Malaysia's political system has created uneasy relations between federal and state authorities over the management of natural resources. Malaysia is a federal representative democratic constitutional monarchy and power is split between the federal parliament and the thirteen state assemblies. Water affairs remain largely under the purview of state governments meaning that revenue generated from water supply services and decisions pertaining to water management are controlled by state water utilities. Since independence from Britain in 1957 one ruling coalition party, Barisan Nasional ${ }^{2}$ has remained in power at the federal level whilst power has moved between parties at a state level. As such state governments in opposition to the national ruling coalition have tended to resist federal policies, including water policies that divert revenue away from the states and where state power is ceded to the federal government. By 2015 only six out of eleven states in Peninsular Malaysia (East Malaysia has so far been excluded from the policy) had implemented the asset light policy. In the five states that have not implemented the policy, limited progress has been achieved on implementing the reforms - referred to as a 'policy impasse' - despite numerous discussions between state and federal government officials.

This paper helps to explain this continuing impasse. In Part I, we briefly review political ecology and post-colonial theory as conceptual frameworks to be employed in the analysis. In Part II, we examine the colonial history of water supply development in Malaysia as means to determine the extent to which colonial policies set the material and discursive foundation for the modern-day water sector. This part also describes the development of the sector in the decades following independence and provides a detailed description of the asset light policy. In Part III, we analyse the effects of the asset

\footnotetext{
${ }^{2}$ In 1957 the Alliance Party was formed which comprised of three parties: United Malays National Organisation (UMNO), Malaysian Chinese Association (MCA) and Malaysian Indian Congress (MIC). In 1973 the name of the coalition was renamed to Barisan Nasional.
} 
light policy from three perspectives: i) operational \& financial; ii) political; and iii) environmental; followed by a discussion of the results and conclusions.

The rationale for this analysis is as follows. We seek to understand how the asset light policy has affected the routine provision of potable water, focussing on indicators of performance and 'financial health', including the necessary treatment and distribution of water, repair of damaged infrastructure and attention to the specific needs of different communities, including low-income groups ${ }^{3}$. Judged by these criteria, the relatively positive, though qualified, outcomes in the states that have implemented the asset light policy prompt analysis of why some states remain so resistant to the policy.

This analysis is informed by a mixed-methods approach to data collection, drawing in particular on fifteen semi-structured interviews with national level policy makers, policy consultants and water utility managers, and analysis of water industry reporting statistics for eleven water utilities and national level water policy documents.

\section{Part 1}

\section{Framing the analyses}

Defined as an 'approach but far from a coherent theory of the complex metabolism between nature and society' (Johnston et al, 2000: 590), political ecology offers an analysis of natural resource management in socio-political terms, considering the historical, political and economic contexts at different spatial and temporal scales (Budds, 2004). Political ecology approaches aim to 'unravel the political forces at work in environmental access, management and transformation' (Robbins, 2012: 3) placing emphasis on plurality of explanation rather than cause and effect and a shift from a positivist to an interactionist approach in environmental research (Budds, 2004). As Castree (2001) surmises the aim is to move towards a more complex analysis instead of a 'face value' assessment.

Typically political ecology scholars draw insights from a range of critical theories including green materialism, peasant studies, feminism, science studies and postcolonial theory (Robbins, 2012). With a primary focus on the specific sites of (de)colonization, postcolonial theory is understood as a 'deep engagement with the role of power in the formation of identity and subjectivity and the relationship between knowledge and political practices' (Abrahamsen 2004, 197). Employed as a means to 'look back to see forward' (Wily 2012: 751) postcolonial analyses focus on identifying patterns of continuity and change in colonial power relations over time. Despite origins within literary studies, postcolonial scholarship is concerned with contemporary issues and themes, such as public health strategies (Brown and Bell, 2008), international aid (Richey and Ponte 2011), and land grabbing in postcolonial Africa (Manzo and Padfield, forthcoming).

Water policy reform in postcolonial states is a particularly fertile ground for studies in political ecology that attempt to unpack the manner in which policy has been (re)formulated, the political and material agendas that these policies serve, and the implications for various groups and communities. For example, in examining the historical origins of water and sanitation development in former colonies, postcolonial scholars have revealed a social construction of water inequality which challenges apolitical explanations for contemporary uneven water access, such as managerial or institutional inefficiency (Kazimbaya-Senkwe, 2005; Padfield, 2011; Smith, 2004). In a landmark

\footnotetext{
${ }^{3}$ Access to potable water in the states of Peninsular Malaysia is approximately 96 per cent (Chin, 2008); thus, assessing the impact of the asset light policy on water access is not of primary concern. Rather the success of the policy is judged in terms of the impact on the operational and financial health of the water utilities themselves.
} 
political ecology study of urbanisation in Guayaquil, Ecuador, Swyngedouw (1997) stresses the need to investigate political and ecological histories as a means to explain water inequalities in urban settings. He argues in cities where there are challenging water supply conditions 'mechanisms of exclusion from and access to water lay bare how both the transformation of nature and the urbanization process are organized in and through mechanisms of social power' (Swyngedouw, 1997: $312)$.

In recent years a growing number of scholars have focused on the privatisation and commercialisation of public utilities, particularly water supply infrastructure (Bakker, 2008; Bayliss, 2002; Budds, 2004; Bywater, 2012; Smith, 2004; Swyngedouw et al, 2002; Yeboah, 2006). Beyond the relatively widespread critique that private water provision has failed to address water inequality in developing countries (Hall \& Lobina, 2006; Padfield, 2011; Smith, 2004), Michael Goldman (2005) argues that neoliberal water discourses often serve to strengthen political power for those in decision-making positions. Goldman's argument recalls Ferguson's notion of an 'instrument-effect' (1990) as elucidated in his account of a World Bank sponsored water development project in Lesotho in the 1980s. Ferguson argues that looking specifically at the interaction of the water development project with the governance of the state allowed him to see the complex relations between the intention of planning and the strategic intelligibility of outcomes. In the case of Lesotho, the 'instrument-effect' of the project was far greater state control in a region that was not previously under such close scrutiny from the authorities. The World Bank development project was thus understood as something with far reaching political consequences. Political ecology aims to understand both the intended as well as the unintended outcomes of environmental and natural resource policies and development plans, how these have evolved, and what pre-conditions (including colonialism) influence this evolution.

\section{Part II}

\section{“Looking back to see forward": The colonial origins of Malaysia's uneven water sector}

Analysis of historical records reveals the defining role British colonialism played in setting the foundation for contemporary urban development in Malaysia. Dating back to the late 18th century the British colonial rulers instigated the construction of a modern day water supply and sewerage infrastructure in various locations in the country. As shown in Figure 1 the earliest water supply infrastructures were constructed in a number of sites on the west and south of Peninsular Malaysia as well as in Kuching town in Sarawak (MWA, 2005; PWD, 1998).
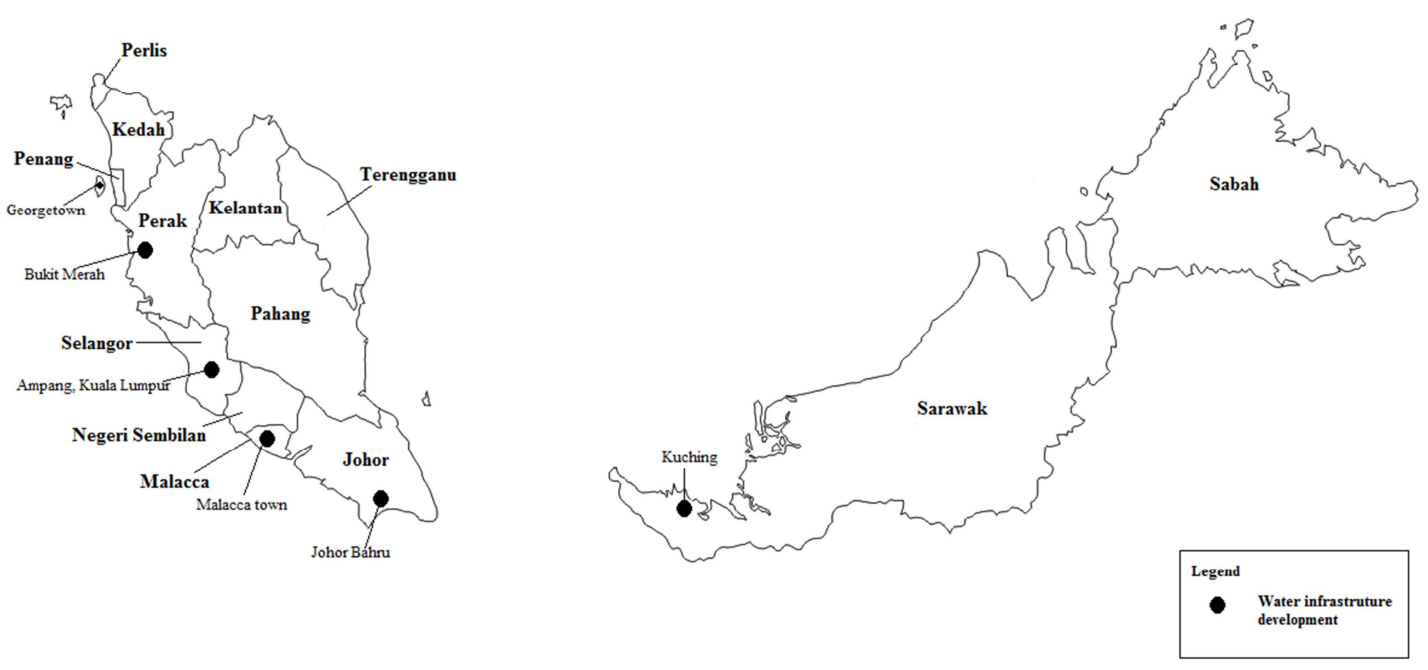
Figure 1: Sites of water supply infrastructure in colonial Malaya by 1932 as documented in governmental records.

Source: PWD, 1995, 1998, 1999; MWA, 2007; Syed, 2014.

Table 1: Documented evidence of water supply development in Malaya, 1804 -1952

\begin{tabular}{|c|c|c|}
\hline Location & Type of Infrastructure & Year built \\
\hline \multirow[t]{3}{*}{ Penang } & $\begin{array}{l}\text { First formal arrangement for a water supply system } \\
\text { - Waterfall Plant } \\
\text { - aqueduct of brick (replaced with a cast iron in } 1877 \\
\text { to transport clear stream water from the hills to town) } \\
\text { - earthen pipes were laid under the streets to transfer } \\
\text { the water through tin pipes to the houses in the town }\end{array}$ & 1804 \\
\hline & Rapid gravity filter of Ayer Hitam & 1934 \\
\hline & Guillemard Reservoir & 1941 \\
\hline \multirow[t]{4}{*}{ Malacca } & $\begin{array}{l}\text { Piped water supply in Malacca town and an } \\
\text { impounding reservoir at Ayer Keroh was constructed } \\
\text { by Corps of Royal Engineers }\end{array}$ & 1898 \\
\hline & Impounding reservoir at Asahan in Jasin & 1930 \\
\hline & Water filter plant in Duyong & 1936 \\
\hline & Bukit Sebukor Water Supply System & 1952 \\
\hline \multirow[t]{2}{*}{ Sarawak } & $\begin{array}{l}\text { First water supply system, Kuching with the capacity } \\
\text { (450,000 litres per day) to support } 8,000 \text { households }\end{array}$ & 1887 \\
\hline & $\begin{array}{l}\text { Matang dam with the storage capacity of } 16 \text { million } \\
\text { litres and the laying of } 18 \mathrm{~km} \text { of pipelines }\end{array}$ & 1907 \\
\hline \multirow{4}{*}{$\begin{array}{l}\text { Selangor / } \\
\text { Kuala } \\
\text { Lumpur }\end{array}$} & $\begin{array}{l}\text { Ampang Impounding in Selangor / Maxwell Hill } \\
\text { reservoir }\end{array}$ & 1898 \\
\hline & $\begin{array}{l}\text { Slow sand filter of Ampang Intake with capacity of } 15 \\
\text { mld (increased to } 18 \mathrm{mld} \text { ) / Weld Hill reservoir }\end{array}$ & 1906 \\
\hline & $\begin{array}{l}\text { Disinfection technology (hypochlorite and later, the } \\
\text { use of gaseous chlorine) }\end{array}$ & 1915 \\
\hline & Kuala Sheh Headwork (28 mld) / Sentul Reservoir & 1928 \\
\hline \multirow[t]{2}{*}{ Johor } & Dams in Gunong Pulai II and Pontian (12 mgd) & 1932 \\
\hline & Labong dam & 1949 \\
\hline \multirow[t]{2}{*}{ Perak } & Bukit Merah dam & 1906 \\
\hline & Chenderoh Hydroelectric & 1930 \\
\hline
\end{tabular}

Source: PWD, 1995, 1998, 1999; MWA, 2007; Syed, 2014 
The sites selected for infrastructural development were largely a reflection of the colonial government's own economic interests. These locations included the naval and strategic trading island of Penang, mining areas within the vicinity of Kuala Lumpur, the port towns of Malacca, Johor and Kuching, and pockets of rural water supply development in Peninsular Malaysia to support agriculture. Water development in these regions flourished as the British imported their own water and sewage treatment and distribution technologies, such as brick aqueducts to transport clear stream water from the upper catchments, earthen pipes, disinfection treatment and rapid sand filters (see Table 1). Reservoirs and dams were also constructed which facilitated urbanisation (i.e. Penang and Malacca), as well as specific industrial and agricultural activities, such tin mining (Selangor) and rubber plantations (Perak). Whilst the British introduced a 'modern' water supply system to Malaya and in the process trained local engineers to design and construct water and sanitation treatment plants (MWA, 2005), not all areas of the country benefitted equally. Towns, villages and rural areas with limited perceived economic potential for the colonialists were largely overlooked in the planning and construction of water supply infrastructure (Tajuddin, 2012). Tajuddin (2012: 67) sums up the inequalities that characterised colonial development in Malaya at that time:

The uneven nature of capitalist development occurring across urban centres, rural areas, and agro-estates in Malaya also carries massive discrepancies in the provision of clean water, sanitation services and accessible medical facilities.

A partial pattern emerges when comparing this history of water supply development in Peninsular Malaysia with the unevenness of the asset light policy adoption. With the exception of Selangor, the places that were first developed for water supply correspond with states that have successfully implemented the water policy regime; namely Penang, Johor and Malacca. Conversely, four of the most historically marginalised states in water supply, Kelantan, Terengganu, Kedah and Pahang continue to resist the policy. Whilst the 'policy impasse' cannot simply be understood in terms of historical legacies - as discussed below - examining the history of water sector development in a postcolonial country, such as Malaysia, provides a starting point for a deeper analysis into the origins of water inequalities and uneven development.

In addition to the physical development of water systems, British colonial rule had a direct influence on legislative issues related to water rights. In 1920, the British introduced the Water Act as a means to consolidate the power of individual states over matters related to water within their borders. Before 1920 state ownership of water was acknowledged and practiced without any written rule. The Act still in force in today (Wiryomartono, 2013) - has led to a decentralisation of water governance and legitimisation of state authority in the domain. It is another significant factor in explaining the uneven adoption of contemporary water reforms.

\section{Visions of modernity: Malaysia's 'asset light' water policy reform}

In the two decades following Malaysia's independence in 1957, neither urban nor rural water sector development was given high priority. With the exception of the Sixth Malaysia Plan where there was a small reduction in the allocation of funds compared to the previous plan, overall there has been a steady increase in public funds allocated to the water sector since 1980 (Table 2). Reflecting a broader trend of the concentration of public resources to support the development and growth of towns and cities, water and sanitation infrastructure development was largely concentrated in those urban areas where high population growth and industrial activities were located (JBA, 2012). 
Table 2: Allocations for water infrastructure under Malaysia national planning

\begin{tabular}{lcc}
\hline Malaysia Plan & Period & $\begin{array}{c}\text { Total capital allocation } \\
\text { Malaysian Ringgit (MYR) } \\
\text { (million) / US Dollar (USD) } \\
\text { (million) }\end{array}$ \\
\hline First Malayan Plan & $1956-1960$ & $\begin{array}{c}\text { Negligible } \\
\text { Second Malayan Plan }\end{array}$ \\
First Malaysia Plan & $1961-1965$ & Negligible \\
Second Malaysia Plan & $1966-1970$ & Negligible \\
Third Malaysia Plan & $1971-1975$ & 538 / 234 \\
Fourth Malaysia Plan & $1976-1980$ & $2,085 / 887$ \\
Fifth Malaysia Plan & $1981-1985$ & 2,348 / 870 \\
Sixth Malaysia Plan & $1986-1990$ & 2,089 / 803 \\
Seventh Malaysia Plan & $1991-1995$ & 2,385 / 745 \\
Eighth Malaysia Plan & $1996-2000$ & $4,000 / 1,081$ \\
Ninth Malaysia Plan & $2001-2005$ & $8,200 / 2,485$ \\
\hline
\end{tabular}

Source: (EPU, 2010)

By the late 1980s, policy makers were drawn towards private finance and neoliberal policies. Such policies were perceived as the 'solutions for state governments to meet growing demand and deal with escalating costs, poor efficiency, and low tariffs' (Tan, 2012: 2556), and to meet the challenge of decades of under investment. This also reflected the prevailing and broader global trend, powerfully backed by leading international agencies such as the World Bank (Goldman, 2005). An initial failed experiment with water privatisation exposed the sector's frailties to aggressive and highly commercial domestic and international water markets (Tan, 2012), including a high profile contract cancellation between the Kelantan state government and the international water utility firm, Thames Water Ltd (Bala \& Muniraju, 2013).

By the mid-2000s Malaysia sought a different policy solution to water privatisation but one that aimed to transform the sector into one more compatible with neoliberal philosophies of water provision. The objective was to enable greater access to sources of finance external to the public purse but in a manner that protected against exploitative practices as experienced during the failed water privatisation attempt. Drafted by a leading consultancy firm, KPMG, the asset light policy was developed in 2006 and passed into national law in 2008. The main thrust of this policy was to allow state water utilities to focus purely on the business of water supply operations (i.e. water treatment, distribution, leakage repair, revenue collection) whilst centralising the ownership and financing of

\footnotetext{
${ }^{4}$ Conversion of MYR to USD derived from historical exchange rates. Source: http://www.tradingeconomics.com/malaysia/currency
} 
water assets at the federal level (Pigeon, 2012). The policy rests on the assumption that professional financiers - with superior knowledge and access to more diverse sources of private and public finance - are better qualified than water engineers to raise revenue from domestic and international capital markets for capital expenditure $\left(\mathrm{CAPEX}^{5}\right)$ purposes. A key pre-condition of the policy is for water utilities to transform themselves into commercial entities, referred to as commercialisation.

As discussed above, since the early twentieth century management of water resources (i.e. rivers, lakes, reservoirs) and the supply of potable water to urban and rural populations has been under the authority of state governments. It was the aim of policy makers to set the legal framework for the asset light policy by convincing state governments to relinquish their power to the federal government over water supply affairs. To achieve the overall aim of the asset light policy, including the legal precedence to facilitate policy implementation, four specific policies (referred to collectively as the asset light policy) were introduced.

First, in 2006 the National Constitution was amended so that matters of water supply were moved from what is known as the 'State List' (i.e. matters in control entirely by the states) to a 'Concurrent List' (i.e. matters in control by both state and federal governments) (MWA, 2006). This legally allowed the federal government to take control of matters related to water supply but only once the state governments had formally agreed to adopt the asset light policy.

Second, the legal framework for the asset light policy was consolidated via two parliamentary acts: the Water Services Industry Act, (Act 655 [WSIA 2006]) and the National Water Services Act (Act 654 [SPAN, 2006]). These Acts empowered the federal government to manage all water supply affairs from water extraction to its distribution as well as sewerage services under the newly appointed national regulator called Suruhanjaya Perkhidmatan Air Negara (SPAN). SPAN's principle roles are to regulate, evaluate and enforce compliance with the legislation (Chin, 2008).

Third, and the most unique component of the policy, was the implementation of an 'asset light' management-financing mechanism where a federal body with links to various sources of private and public finance is responsible for finding financing sources for CAPEX expenditure. In return, water utilities are required to sell their water infrastructure assets to the federal government. These are subsequently leased back to the utilities for a period of 30-50 years. The federal government created and tasked an independent public company, Pengurusan Aset Air Berhad (PAAB) under the direct authority of the Ministry of Finance, to handle the transfer of asset ownership between state and federal governments and to source finance for infrastructure investment (Chin, 2008). According to Chin (2008), PAAB seeks funding from several sources and these include domestic capital markets, domestic bond markets, pension funds, governmental funding, leasing the water assets to the water utilities, and international markets.

Finally, a significant precondition of the aforementioned restructuring was the commercialisation of public water utilities. Commercialisation refers to the transformation of state government-controlled utilities into independent, profit orientated companies whilst retaining public ownership i.e. a minimum of fifty-one percent of company shares must be owned by the state government. These transitions in water governance and operating philosophy of water utilities constitute a significant transformation of pre-existing governance arrangements. Figure 2 shows the different agencies and roles in the asset light policy.

\footnotetext{
5 Funds invested by a water utility to acquire or upgrade fixed, physical, non-consumable assets, such as buildings and equipment.
} 


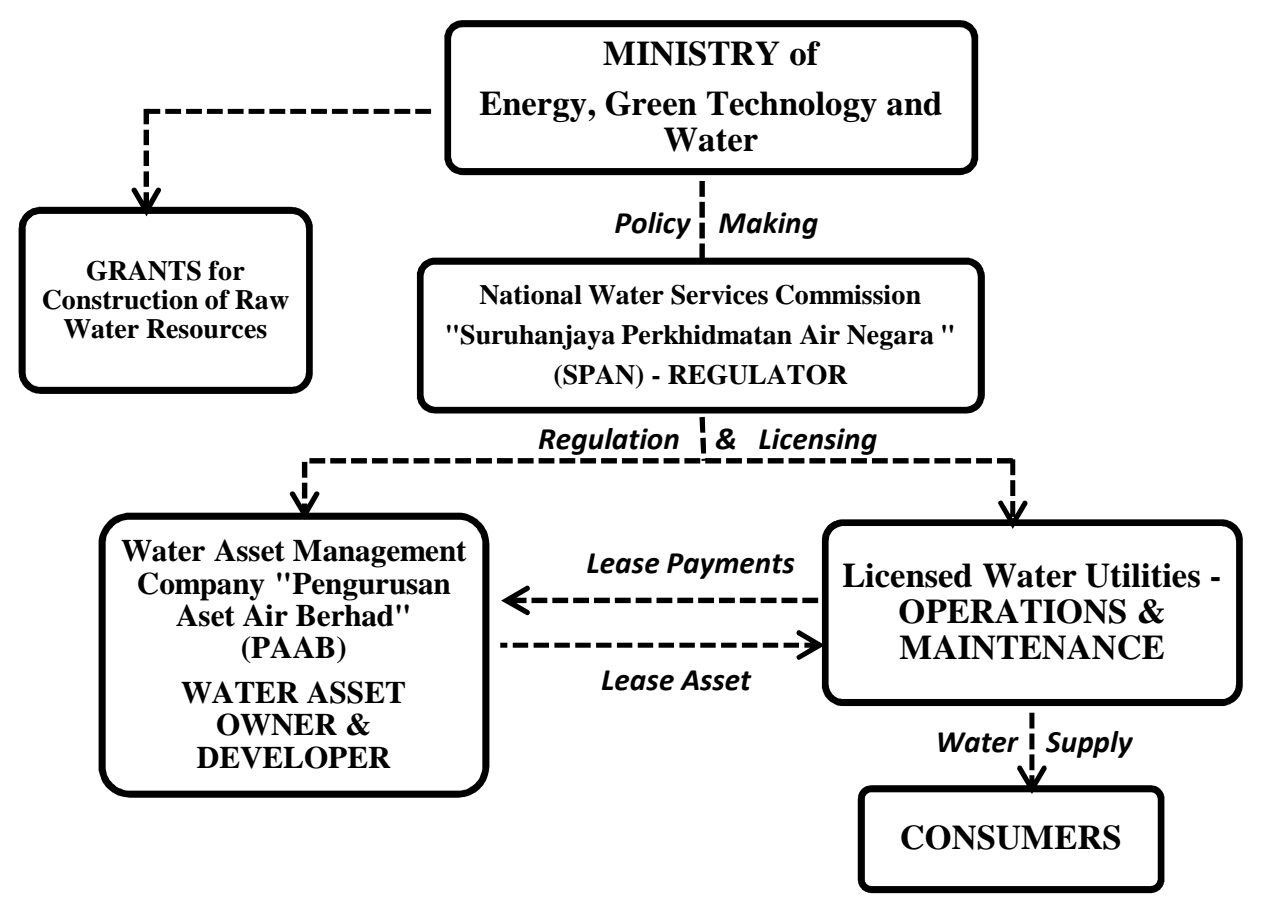

Figure 2: The roles of key stakeholders following the implementation of the asset light policy in 2008

Source: Adapted from Chin, 2008

Since implementation of the asset light policy in 2008, only six of the eleven states have implemented the policy. These six states implemented within a four year period with the latest state, Perak, implementing the policy in 2012. In the other five states of Peninsular Malaysia a 'policy impasse' exists. The five respective state governments have refused to adopt the policy and thus water utilities in these states continue to operate under the previous policy framework. The state governments of East Malaysia, Sabah and Sarawak chose to be excluded from the asset light policy due to concerns of a loss of sovereignty (Chin, 2008).

\section{Part III}

\section{Impacts of the asset light policy}

\section{Operational and financial perspectives}

Overall, analysis of operational and financial performance criteria reveals uneven results when comparing water utilities in states that have implemented the policy and water utilities in states that have not (referred to as 'implementing' and 'non-implementing' states, respectively). Figures 3 and 4 show the difference in non-revenue water (NRW) between the states over the period $1992-2012$. NRW is used as a proxy of operational and financial performance since it indicates how efficiently the utilities are distributing treated water to consumers and obtaining revenue in return. Reductions in NRW can be achieved by closely monitoring leakages and clamping down on 'illegal' water taking and non-payment. Reducing NRW requires resources and a degree of financial stability; those companies which can successfully reduce NRW are thus more likely to be well performing from an operational and financial perspective. 
With the exception of Perlis where limited financial resources and decades of underinvestment in necessary infrastructure have plagued efforts to reduce NRW (Interview, utility manager \#4, September 13, 2013), since 2007 the other implementing states have seen steady reductions in NRW. The largest margin of improvement is in the state of Negeri Sembilan where NRW has dropped from 60 percent in 2006 to 40 percent in 2012. A number of water utilities stated that the submission of three-year business plans and regular reporting on financial and key performance indicators (KPIs) - a component of the asset light policy - has led to a very positive and immediate impact on operations, such as NRW (Interview, utility manager \#3, November 15, 2013; Interview, utility manager \#4, September 13, 2013).

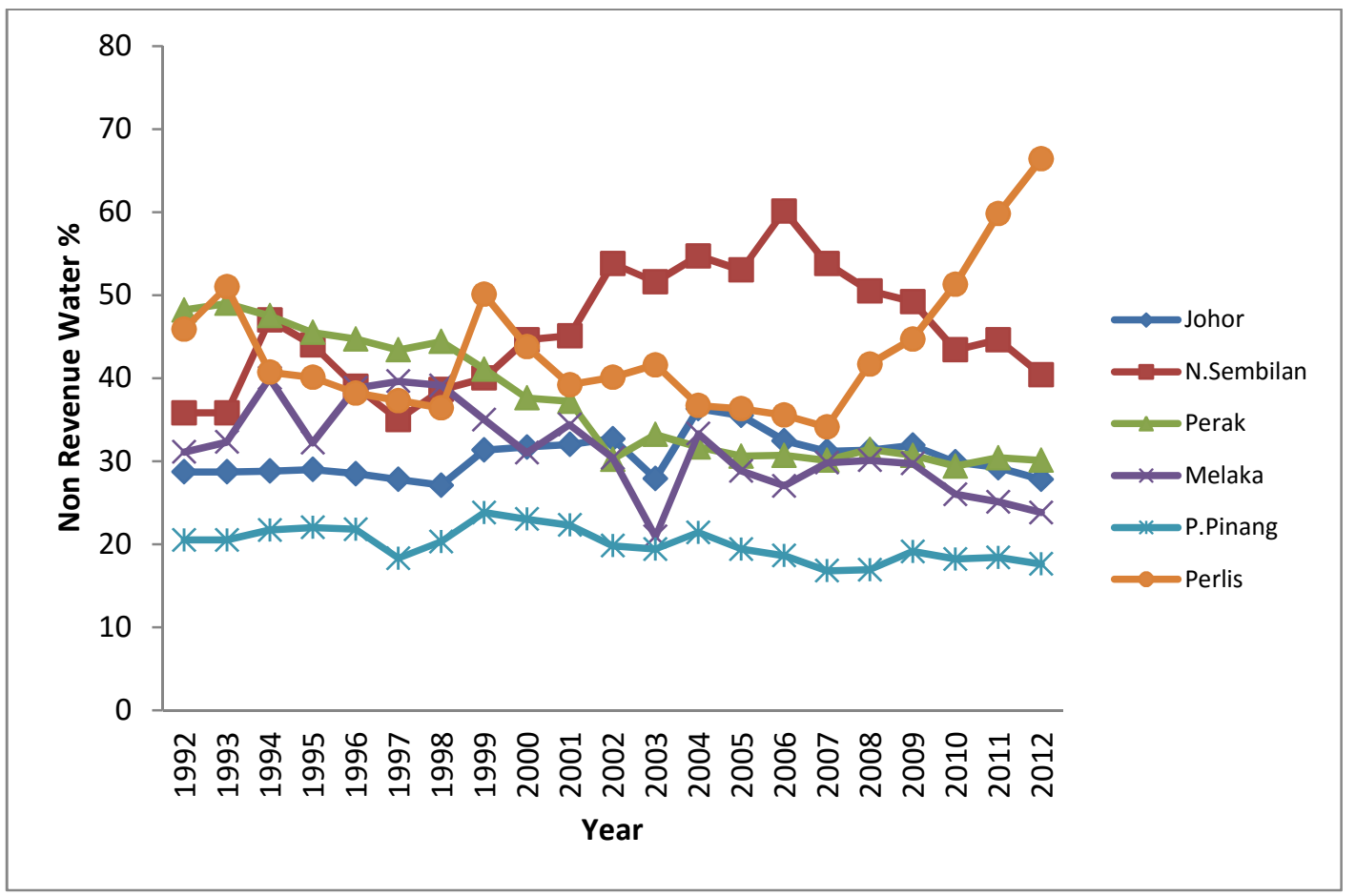

Figure 3: Non-revenue water in the states that have implemented the asset light policy

Source: Water industry reports 1993 - 2012, public surveys, public and private utility's annual financial and performance reports. 


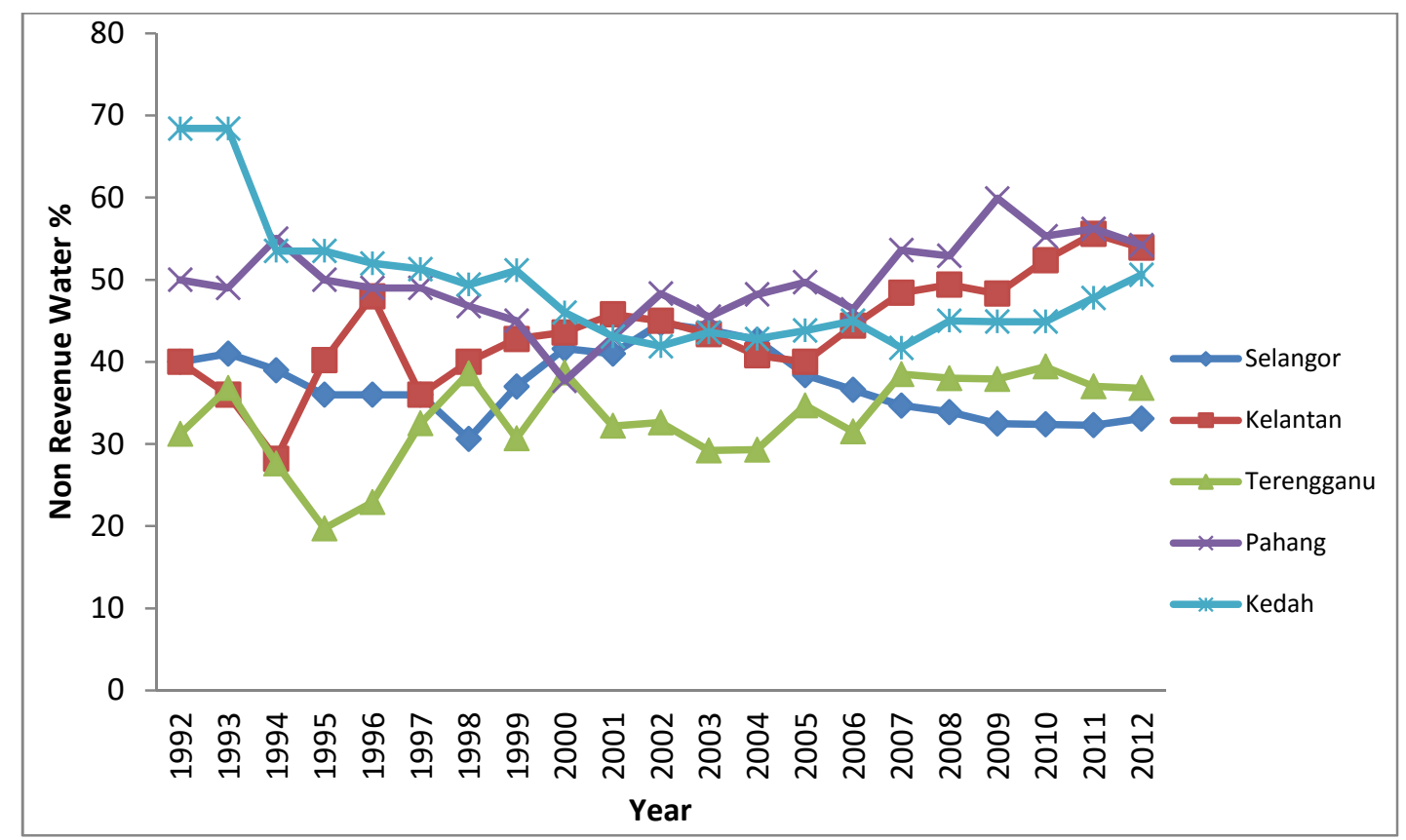

Figure 4: Non-revenue water in the states that have not implemented the asset light policy

Source: Water industry reports 1993 - 2012, public surveys, public and private utility's annual financial and performance reports.

In non-implementing states, with the exception of Selangor, NRW has increased since 2006. The states of Kelantan and Pahang both have NRW approaching 60 percent which indicates a high loss of treated water as well as potential revenue. The average NRW for non-implementing states is 45 percent whilst the figure is almost ten per cent lower in the implementing states. Whilst there is the expectation that the non-implementing states will submit business plans and KPIs to SPAN, since these states operate under the previous policy framework - and, importantly are not answerable to SPAN - there is no obligation to report information on their operational activities and targets. (Interview, consultant policy maker, July 23, 2013; Interview, industry regulator, October 16, 2013). Furthermore, there is less incentive for the utilities in non-implementing states to meet performance targets since they are not eligible for CAPEX loans from PAAB. Only implementing states have this option which is to their benefit since investments in CAPEX can help improve the quality of services (e.g. the construction of new pumping stations can increase water pressure to households) which, in turn can help bill collection (Interview, consultant policy maker, July 23, 2013).

Likewise comparing the ratio of revenue against operating expenditure $\left(\mathrm{OPEX}^{6}\right)$ for utilities in implementing and non-implementing states reveals generally stronger financial performance by the former. In figures 5 and 6, utilities in implementing states are generally showing signs of better financial health compared to those in non-implementing states. Prior to policy adoption water utilities in Johor, Penang, Perak and Melaka appeared to have entered a relative 'comfort zone' whereby their net revenue was sufficiently large and flexible to either cross subsidize across their operational activities (i.e. water supply and treatment), further invest in OPEX or make investments to generate future income. This may help to explain why the net revenues of certain utilities, notably those in

\footnotetext{
${ }^{6}$ Funds needed to meet the daily operational expenses of water utilities such as payment of staff salaries, vehicle and office rental costs, chemicals and energy costs for water treatment, etc.
} 
states which have implemented the asset light policy, have not increased significantly yet their nonrevenue water has constantly decreased. A senior manager from one of the implementing state utilities explains:

"They [the regulator, SPAN] always use our NRW to show how good the reform is to us but people do not know our darker side... the financial part. Especially how much money we pour and invest just to lower the NRW to fulfil the requirement of SPAN...But it is good I will say, for the future. The current investment is needed. That we can get back in future" (Interview, utility manager\#3, November 15, 2013).

The financial health of the utilities in the non-implementing states has a far less positive outlook. Net revenues are low in terms of capacity and flexibility to sustain their operational activities, especially considering all of the utilities in non-implementing states are based in large states with relatively high populations. For the utilities in non-implementing states, revenues must contribute towards CAPEX for flood mitigation or expansion of infrastructure to rural areas. The asset light policy also marks an important shift from past practices where state governments would often use water revenue for nonwater expenditures (Interview, utility manager\#1, July 9, 2013). It is likely that this continues, at least to some degree, in non-implementing states.



Figure 5: Ratio of annual revenues against operational expenditure (OPEX), 2001 - 2011 for water utilities in states that have implemented the asset light policy 


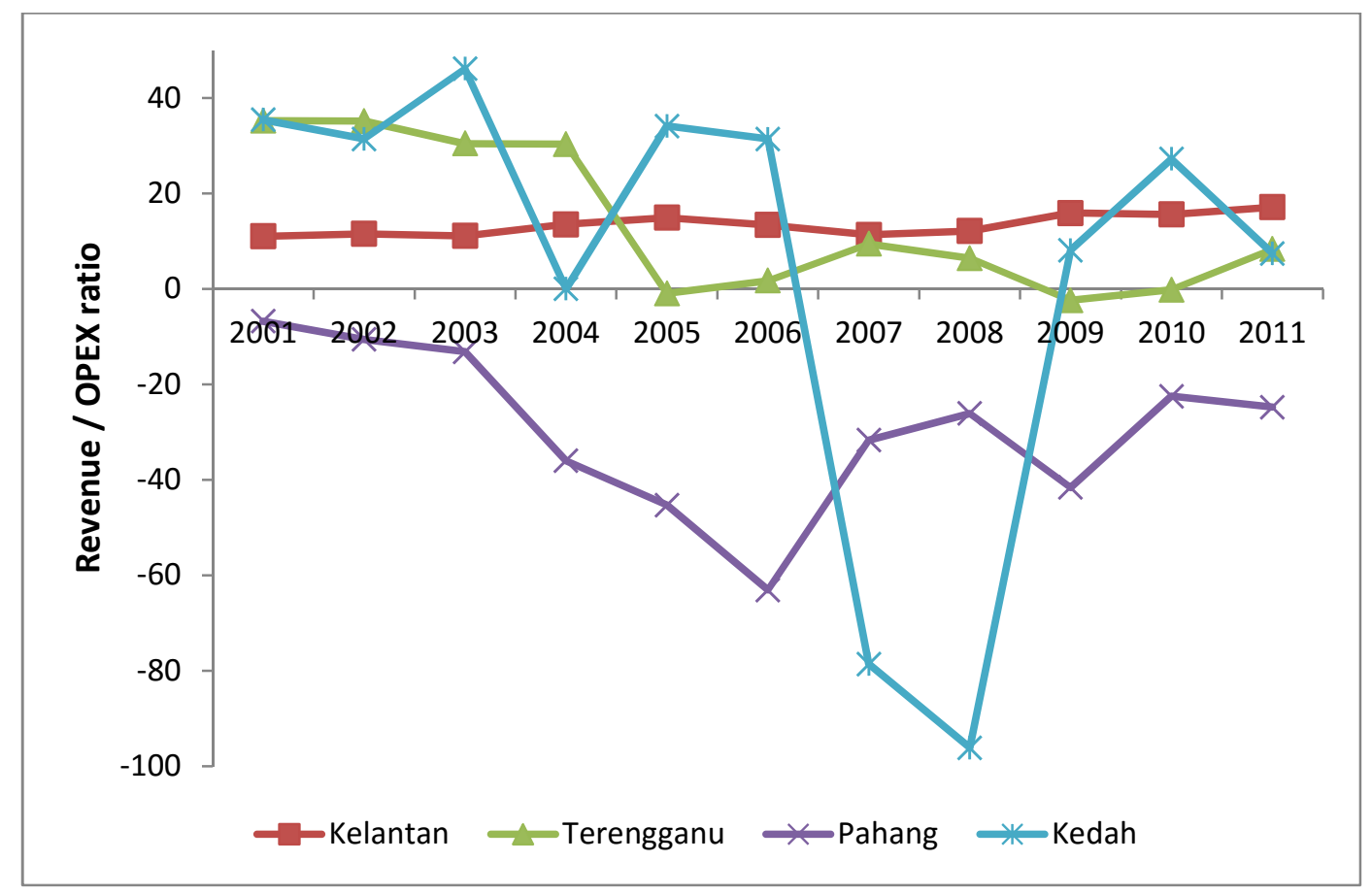

Figure 6: Ratio of annual revenues against operational expenditure (OPEX), 2001 - 2011 for water utilities in non-implementing states. Selangor has been removed due to uncertainties in the data.

Water tariffs have also been affected by the onset of the asset light policy. As shown in Table 3, prior to the implementation of the policy, regular tariff revisions were not common in Malaysia; however, from 2006 there is evidence of tariff revision, especially in the implementing states. Meanwhile, with the exception of Kedah the other four other non-implementing states have not revised their water tariffs for at least 9 years. One of these states, Pahang, has not revised its tariff in 30 years. The range of both domestic and industrial tariffs across the different states also reflects the fragmented nature of the water sector. For example, the domestic water rate in Johor is three times higher than in Penang (RM $1.05 / \mathrm{m}^{3}$ and $\mathrm{RM} 0.31 / \mathrm{m}^{3}$, respectively). Historically, state governments have set the water tariff as well as the frequency of tariff revisions. Due largely to the political importance of cheap water, tariffs have been maintained at very low rates for decades. The asset light policy, however, challenges past practices and perceptions of the social, economic and political values of water. In particular, the policy emphasises the commercial value of water supply services which includes water tariffs that reflect the economic costs associated with its treatment, distribution and maintenance of infrastructure. 
Table 3: Water rates and the most recent tariff review of the state water utilities in Malaysia (MWA, 2011)

\begin{tabular}{|l|l|l|l|l|c|}
\hline $\begin{array}{l}\text { Status of } \\
\text { policy } \\
\text { adoption }\end{array}$ & State & $\begin{array}{l}\text { Domestic } \\
\text { rate } \\
\mathrm{RM} / \mathrm{m}^{3}\end{array}$ & $\begin{array}{l}\text { Last tariff } \\
\text { review }\end{array}$ & $\begin{array}{l}\text { Industrial } \\
\text { rate } \\
\mathrm{RM} / \mathrm{m}^{3}\end{array}$ & $\begin{array}{l}\text { Last tariff } \\
\text { review }\end{array}$ \\
\hline Implemented & Johor & 1.05 & 2011 & 2.8 & 2011 \\
\cline { 2 - 6 } & $\begin{array}{l}\text { Negeri } \\
\text { Sembilan }\end{array}$ & 0.68 & 2002 & 1.56 & 2002 \\
\cline { 2 - 6 } & Perak & 0.73 & 2006 & 1.6 & 2006 \\
\cline { 2 - 6 } & Melaka & 0.75 & 2011 & 1.67 & 2011 \\
\cline { 2 - 6 } & Penang & 0.31 & 2011 & 0.96 & 2011 \\
\cline { 2 - 6 } & Perlis & 0.57 & 1996 & 1.3 & 1996 \\
\hline \multirow{2}{*}{\begin{tabular}{l} 
implemented \\
\cline { 2 - 6 }
\end{tabular}} & Selangor & 0.77 & 2006 & 2.27 & 2006 \\
\cline { 2 - 6 } & Kelantan & 0.55 & 2001 & 1.25 & 2001 \\
\cline { 2 - 6 } & Terengganu & 0.52 & 1997 & 1.15 & 1997 \\
\cline { 2 - 6 } & Pahang & 0.57 & 1983 & 1.45 & 1983 \\
\cline { 2 - 6 } & Kedah & 0.67 & 2011 & 1.4 & 2011 \\
\hline
\end{tabular}

\section{Political perspectives}

Stakeholder interviews revealed generally mixed sentiments towards the asset light policy. Such a finding not only reflects the conflicting opinions held by different governmental, non-governmental and water industry actors within Malaysia but also serves to illustrate the overall dilemma faced by policy makers - how to deliver a sustainable and robust funding strategy for a 'public good' such as water that balances financial, political, social and environmental concerns. Specifically, concerns were raised over the loss of public accountability in water governance since the financing mechanism places greater control into federal hands (i.e. the regulator and asset management agency) and away from local actors that generally are more focused on the needs and interests of their communities. Echoing past critiques of water privatisation and commercialisation (Bayliss, 2009; Bakker, 2008), interviewees from the NGO sector, in particular, felt that the underlying outcome of the asset light policy was greater focus on private interests (Interview, NGO, October 10, 2013). Interviewees from the water industry, however, stressed that the asset light policy had ultimately brought social benefit as a result of more streamlined and performance orientated utilities (Interview, water industry consultant, May 5, 2013). 
The challenge of implementing a water policy that balances the needs and expectations of different actors was also revealed when analysing stakeholder views on the social and political impacts of tariff revisions. On the one hand, there was a clear position taken by a number of the stakeholders on the need for more appropriate water pricing. As one interviewee put it:

"I live in [...]. So, the first 20 metres cubic is free. So that's also perplexing. I mean, I, I love the state that I live in. But at the same time, I don't know why we're giving up free water that way. If it's a political ploy, it's darn stupid. Because you don't give away resources like that for free. Kinds of make people undervalue it" (Interview, NGO, October 10, 2013).

Conversely, a number of the interviewees referred to the need for the protection of community interests, especially low income groups who may not be able to afford the tariff increases. This point hits at the heart of what makes the asset light policy contentious: the loss of control over water matters by state governments to federal agencies. Indeed, there has been firm resistance to the policy in states where governments are not aligned with national political parties (Padfield et al, 2014; Tan, 2012). Ceding control over assets and tariffs to the national regulator - perceived as an extension of the federal government in 'opposition states' - is politically too unpalatable to states run by parties in opposition to the national ruling party, Barisan Nasional. As shown in Table 4 below, the states of Selangor and Kelantan are controlled by opposition parties and have firmly resisted the policy since 2006. Whilst Penang implemented the policy in 2011, its strong local economy, large industrial customer base and representation of public interest in the ownership structure have served to allay any negative political and economic impacts of the policy. As the consultant responsible for drafting the asset light policy observed:

“...if you look at it in terms of the end game, there's no dispute between the federal government and the state government. So the only issue is everybody wants to be the boss" (Interview, consultant policy maker, July 23, 2013).

Table 4: Political alignment of the eleven state governments of Peninsular Malaysia in 2015

\begin{tabular}{lcccc}
\hline $\begin{array}{l}\text { States in } \\
\text { Peninsular } \\
\text { Malaysia }\end{array}$ & $\begin{array}{c}\text { Implemented the } \\
\text { asset light policy }\end{array}$ & $\begin{array}{c}\text { Not implemented } \\
\text { the asset light } \\
\text { policy }\end{array}$ & $\begin{array}{c}\text { State government } \\
\text { aligned with } \\
\text { federal } \\
\text { government }\end{array}$ & $\begin{array}{c}\text { State government } \\
\text { aligned with } \\
\text { opposition party }\end{array}$ \\
\hline $\begin{array}{l}\text { Johor } \\
\text { Negeri Sembilan }\end{array}$ & $\sqrt{ }$ & & $\sqrt{ }$ & \\
Melaka & $\sqrt{ }$ & & $\sqrt{ }$ & \\
Pulau Penang & $\sqrt{ }$ & & $\sqrt{ }$ & $\sqrt{ }$ \\
Perlis & $\sqrt{ }$ & $\sqrt{ }$ & $\sqrt{ }$ \\
Perak & $\sqrt{ }$ & $\sqrt{ }$ & $\sqrt{ }$ & \\
Selangor & & $\sqrt{ }$ & $\sqrt{ }$ & \\
Kelantan & & $\sqrt{ }$ & $\sqrt{ }$ \\
Terengganu & & $\sqrt{ }$ & & \\
Pahang & & & & \\
Kedah & & &
\end{tabular}

From the perspective of water utilities in non-implementing states, the 'policy impasse' is perceived to be a double loss. Firstly, the utilities argue that they are held back by a low water tariff which is determined on political grounds rather than by the full cost of water treatment and distribution. 
Secondly, these utilities cannot take advantage of the loans for CAPEX that come with implementing the policy. As one water utility manager explained:

“...as operators you're judged on the service you provide and not the politics. But the politics is influencing your operations. So, to me I see that as a real weakness." (Interview, utility manager \#1, July 9, 2013).

\section{Environmental perspectives}

As described earlier the asset light policy was facilitated by an amendment to the National Constitution to allow greater federal control over matters related to water supply services. Water resources, however, remain firmly within state government jurisdiction - a legacy of British colonial rule as discussed earlier - regardless of whether or not the state has implemented the asset light policy. The deliberate omission of water resources from the constitutional restructuring - a political concession to state governments to allow broader support for the asset light policy - is roundly criticised by water utilities. Four water utilities interviewed as part of this research argued that water supply operations are severely undermined because of the continual degradation of upstream catchments, largely caused by timber logging, industrial activities, and agriculture (Padfield et al, in press). This has led to a diminishing supply of available water for treatment purposes as well as rising treatment costs where water sources are polluted (Interview, utility manager \#1, July 9, 2013). Due to the power held by state governments over land development and management of water resources, federal agencies have limited control over the types of concessions awarded for economic activities. The separation of water resources and water supply is especially problematic for utilities who rely on raw water from catchments in neighbouring states, as demonstrated by on-going disagreements between Penang Water Supply Corporation and the Kedah state government (Interview, utility manager\#3, November 15, 2013).

Moreover, the utilities are required to pay a royalty to the respective state government for the raw water they extract for treatment. The royalty payable to the state is meant for the maintenance of the catchment in order to sustain a good quantity and quality of raw water (Chin, 2008). Despite the state's responsibility as protectors of the water catchment (Chin, 2008), agricultural development, deforestation and industrial activities are often prioritised above water resource management. One utility manager summed up the challenge facing water utilities and society at large: “...if you don't take care of the catchment, you won't have water in the future" (Interview, utility manager \#2, June 19, 2013).

\section{Discussion}

Examined through the lens of selected water industry performance indicators for operation and finance, Malaysia's asset light policy appears to be a success story. The policy has allowed previously debt burdened publicly owned water utilities to 'sell-off' their assets to a specially created federal government agency, PAAB, in return for debt cancellation and access to low or interest-free loans for CAPEX purposes. Commercialisation has brought a more explicit focus on utility professionalism, customer service and strategies aimed at generating higher revenues. For those utilities that have implemented the asset light policy there have been noted improvements in the key indicators of water industry performance (i.e. NRW, tariff revision, revenue generation). Moreover, in all but one state (Johor), majority public sector ownership is retained which helps to ensure that decisions take public concerns into account. 
In contrast, states that have resisted implementing the asset light policy have continued to experience high levels of NRW and poor financial indicators, whilst tariffs largely remain at the same level as in the 1980s and 1990s. Water utilities in these states retain many of the traditions of public sector water governance i.e. there is less focus on the commercialisation of water services and water revenues generated can be taken up by state governments for non-water related expenditure. A logical solution follows that in implementing the asset light policies these states can take advantage of the benefits offered under the policy which, in turn, will help close the gap with those states which have implemented.

Analysed from a political ecology perspective, two arguments are presented below to explain why there is uneven performance between the states that have implemented the asset light policy and those states that have not and why, ultimately, the non-implementing states are unlikely to implement the policy under current conditions.

\section{Commercial transitions in a postcolonial era of uneven water development}

The first argument is that examining the asset light policy within the historical context of national water development provides a starting point to explain the policy's polarizing effect. The origins of Malaysia's uneven water development are rooted in the colonial planning policies of the early 1800s through to the mid-1900s. Urban and suburban water infrastructure development was a focus of the colonial period (Chin, 2008), in part to facilitate the growth of Malaysia's emerging towns and cities. While other regions of the country received pockets of infrastructural development after independence, water sector development in rural and provincial towns was largely overlooked in public financing allocation until the late 1970s (Chin, 2008). The steady concentration of governmental resources in the second half of the century to support the established metropolitan areas thus reinforced the historically embedded uneven water development.

Thus, the implementation of a commercial logic for water provision - a modernist policy reliant on urban piped water networks and a customer base with sufficient income to support regular tariff reviews - is more likely to succeed in locations where such conditions exists. Examined from this perspective it becomes clear that certain states in Peninsular Malaysia are more suited to implement the underlying commercial modus operandi of the asset light policy as compared with others.

Consistent with research examining the impacts of commercial water reforms in postcolonial Africa (Padfield, 2011; Smith, 2004), imposing a commercial logic for water supply provision on top of an already uneven water landscape serves to accentuate differences between the historically developed and less developed water geographies.

Legacies of colonial water development also reveal themselves in matters of water resource governance. A British colonial water law referred to as 'Water Act 1920' ceded power over land and water to state governments. This policy is still in force in the present day and, ultimately, gives state governments control over land (i.e. agricultural and industrial activities) and water development (i.e. river and reservoir management) within their boundaries. As argued below this is critical to understanding the current 'policy impasse' i.e. why the policy has been met with such resistance in certain states.

\section{The 'apolitical policy machine'}

Next, a political analysis of the asset light policy explains why the policy is less favoured in certain states. Such an analysis can help further explain the polarizing impact of the policy. The stated aim of the asset light policy is to achieve long-term financial sustainability across the national water sector 
by promoting efficient and effective operations through good governance (Chin, 2008). While the term 'good governance' does loosely hint at transformations in the institutions that manage and oversee the water sector, the policy does not explicitly account for or address the resultant changes to the political landscape of water provision.

Yet, as illustrated above, the asset light policy has explicit political consequences for water supply governance. Handing over power and control of water assets and, crucially, water tariffs - an issue of common electoral concern - has considerable implications for local communities as well as local political agendas. For states where the water tariff has been politically sensitive, the sudden transfer of control to agencies aligned with the federal government is regarded as unpalatable. As Robbins argues: "To implement new technological approaches in agriculture, resource extraction, or wilderness management requires a transformation of existing institutions...there is nothing apolitical about such a proposal" (Robbins, 2012: 19). Examined in this light it is perhaps unsurprising that a number of state governments aligned with opposition parties are less willing to cede even partial control over local water governance. Interestingly, one of the key policy makers admits that politics is indeed the root of the 'policy impasse': "if there's any one single reason why it's taken so long it's purely politics" (Interview, consultant policy maker, July 23, 2013).

The narrow apolitical scope of the asset light policy can also be seen in the institutional separation of water resources management from water supply. As described earlier, a number of the water utilities suffer from catchment degradation as state governments aim to generate revenue via economic activities such as industrial and agricultural development. However, most of the utilities are arguing for the improved protection of these upper catchments to safeguard future water supply availability. The asset light policy is thus shown to be constructed within a very narrow apolitical scope of water governance, i.e. focusing on water supply services whilst leaving out broader structural reforms related to water resource and catchment management. It appears that difficult and challenging political questions related to land and water rights are nowhere addressed.

\section{Conclusion}

Building on political ecology scholarship in urban water policy and reaffirming postcolonial critiques of neoliberal inspired water policies in developing countries, our paper concludes with two points. Firstly, this study has shown that the twin pillars of the asset light policy, commercialisation and centralisation of water asset ownership, are generally favoured in states where there is a historically well developed urban water infrastructure. Not all the states can be described in this way and thus the current 'one size fits all' policy does not take into account the country's highly fragmented and heterogeneous water sector. Analysing Malaysia's water development through a historical lens helps to locate the origins of the contemporary uneven water landscape which, in turn casts light on why such a policy intervention has varying degrees of acceptance and appeal across the country. As argued elsewhere but relevant in the Malaysian case, it is recommended that water policy makers take into account the roots of water inequalities and uneven water development that characterize many former European colonies (Padfield, 2011; Smith, 2004).

Secondly, this study reveals that the focus of the asset light policy on technical efficiency and improved financial performance has ignored the resultant political outcomes, such as the ceding of control of water tariffs and water assets from the state governments to the federal government. In the past twenty years, research has uncovered the fundamentally political, economic and social outcomes of neoliberal water policies across parts of the global South, as well as political resistance to these policies (Bakker, 2008; Bywater, K., 2012; Yeboah, 2006). The current 'policy impasse' in five of 
eleven states implies a form of local level resistance; thus, overcoming the impasse may be best achieved by policy makers identifying and addressing explicitly the various outcomes of the policy and the political dimensions of these.

\section{Acknowledgements}

The authors wish to acknowledge research funding from the Malaysia Japan International Institute of Technology, Universiti Teknologi Malaysia (Grant No. 4J054). Gratitude is also expressed to Mr. Shaharis Saad from the Malaysian Water Association and Dr. Jeff Tan for his insightful comments on an earlier draft.

\section{References}

Abrahamsen, R., 2003. African studies and the postcolonial challenge. African Affairs. 102(407), $189-210$

Bakker, K., 2008. The Ambiguity of Community: Debating Alternatives to Private Sector Provision of Urban Water Supply. Water Alternatives. 1(2), 236-52.

Bala, J., Muniraju, Y., 2013. Privatisation of Water Resource Management: Looking Beyond Profiteering. Nitte Management Review. 7 (2), 70-78.

Bayliss, K., 2002. Water privatisation in SSA: progress, problems and policy implications. Development Studies Association Annual Conference, University of Greenwich, UK. 9 November 2002 [on-line] www.psiru.org/reports/2002-12-W-DSAAfricawater.doc (Accessed: 07/03/2015).

Brown, T \& Bell, M. 2008. Imperial or postcolonial governance? Dissecting the genealogy of a global public health strategy. Social Science \& Medicine 67 (10), pp. 1571-1579

Bywater, K., 2012. Anti-privatization Struggles and the Right to Water in India: Engendering Cultures of Opposition, in: Sultana, F., Loftus, A., (Eds.), The Right to Water. Earthscan Publishers., London, 206-222.

Budds, J., 2004. Power, nature and neoliberalism: the political ecology of water in Chile. Singapore Journal of Tropical Geography. 25(3), 322-342. doi:10.1111/j.0129-7619.2004.00189.x

Castree, N., 2001. Commodity fetishism, geographical imaginations and imaginative geographies. Environment and Planning. 33(9), 1519 - 1525.

Chin, Y. 2008. The Water Tablet: Malaysian Water Reforms. Ministry of Energy, Water and Communications. MPH Group: Kuala Lumpur, Malaysia.

Collins English Dictionary, 2003. English Dictionary: Complete and Unabridged. Collins: Standard Sixth edition.

Economic Planning Unit, 2010. Tenth Malaysia Plan 2011-2015. Putrajaya, Malaysia.

Ferguson, J. 1990. The anti-politics machine: Development, depoliticization and bureaucratic power in Lesotho. Minnesota: University of Minnesota Press

Goldman, M., 2005. Imperial Nature: The World Bank and struggles for social justice in the age of globalization. Yale University Press. 
Hall, D. and Lobina, E., 2006. Pipe dreams: The failure of the private sector to invest in water services in the developing countries. Public Services International Research Unit [online] Available at http://www.wdm.org.uk/resources/reports/water/pipedreamsreport01032006.pdf

Jabatan Bekalan Air (JBA), 2012. A Glimpse at Water Supply in Malaysia: Past and Present. Putrajaya, Malaysia.

Johnston, R., Gregory, D., Pratt, G., Watts, M., Smith, D., 2000. The Dictionary of Human Geography, fourth ed. Oxford, Blackwell.

Kazimbaya-Senkwe, B., 2005. The social construction of access to water in Zambia's Copperbelt: Beyond the managerial explanation for inadequate access. Thesis (PhD). Newcastle University.

KPMG, 2015. Services. http://www.kpmg.com/global/en/services/Pages/default.aspx (Accessed: 15/04/2015).

Malaysia Water Association, 2005. Malaysia Water Industry Guide 2005. Kuala Lumpur, Malaysia: Malaysia Water Association. KDN no. PP 11667/10/2005 ISSN: 1675-2384.

Malaysia Water Association, 2007. Malaysia Water Industry Guide 2007. Kuala Lumpur, Malaysia: Malaysia Water Association. KDN no. PP 11667/10/2007. ISSN: 1675-2384.

Malaysia Water Association, 2011. Malaysia Water Industry Guide 2011. Kuala Lumpur, Malaysia: Malaysia Water Association. KDN no. PP 11667/06/2011(026995).

Manzo, K \& Padfield, R. (forthcoming) Neoliberal Colonialism? A Postcolonial Reading of "Land Grabbing” in Africa in: J. Singh \& D. Kim (Eds). Postcolonial World. Routledge.

Padfield, R., 2011. Neoliberalism and the Polarizing Water Geographies of the Zambian Copperbelt. Waterlines. 30(2), 150-164.

Padfield, R., Drew, S., Papargyropoulou, E., Page, S., Evers, S., Hansen, S., Campos-Arceiz, A., Schouten, G., Kangayatkarasu, N., Maulidia, M., Sayok, A., Syayuti, K \& Mun Hou, T. Landscapes in transition: An analysis of sustainable policy initiatives and emerging corporate commitments in the palm oil industry (in press) Landscape Research

Padfield, R., Richards, C., Yusop, Z., Parkey, J., Harrison, O., Preece, C., 2014. Tackling wicked problems in the Malaysian water industry: A framework for University-Industry research partnerships. Journal of Governance and Development.

Pengurusan Aset Air Berhad (PAAB) (2010). Annual Report 2010. Kuala Lumpur, Malaysia.

Pigeon, M., McDonald, D.A., Hoedeman, O., Kishimoto, S., 2012. Remunicipalisation: Putting Water Back into Public Hands. Transnational Institute, Amsterdam.

Prasad, N., 2007. Privatisation of water: a historical perspective. LEAD J. 217.

Public Works Department (PWD), 1995. Malaysia Water Industry Report 1995, Kuala Lumpur, Malaysia: Malaysia Water Association. JKR 20200 - 0030 - 95.

Public Works Department (PWD), 1998. Malaysia Water Industry Report 1998, Kuala Lumpur, Malaysia: Malaysia Water Association. JKR 20200 - 0040 - 98. 
Public Works Department (PWD), 1999. Malaysia Water Industry Report 1999, Kuala Lumpur, Malaysia: Malaysia Water Association. JKR 20200 - 0049 - 99.

Richey, L.A., Ponte, S., 2011. Brand aid: shopping well to save the world. University of Minnesota Press.

Robbins, P. 2012. Political Ecology. Second Edition. Wiley-Blackwell. Chichester: UK.

Smith, L., 2004. The murky waters of the second wave of neoliberalism: corporatization as a service delivery model in Cape Town. Geoforum. 35(3), 375-393.

Swyngedouw, E., 1997. Power, nature and the city: the conquest of water and the political ecology of urbanization in Guayaquil, Ecuador: 1880-1990. Environment and Planning A 29 (2), 311-332

Swyngedouw, E., Kaïka, M. \& Castro, E. (2002) Urban Water: A Political-Ecology Perspective. Built Environment Vol. 28, No. 2, Water Management in Urban Areas, pp. 124-137

Syed, M. S., 2014. A dammed future? Exploring the vialibility of dams for Malaysian water resource development. 23 ${ }^{\text {rd }}$ Annual Professor Chin Fung Kee Lecture 2013.

Tajuddin, A., 2012. Malaysia in the World Economy (1824-2011): Capitalism, Ethnic Divisions, and "managed" Democracy. Lexington Books.

Tan, J., 2012. The Pitfalls of Water Privatization: Failure and Reform in Malaysia. World Development. 40(12), 2552-2563.

Wily, L., 2012. Looking back to see forward: the legal niceties of land theft in land rushes. Journal of Peasant Studies. 39(3-4), 751-775

Wiryomartono, B., 2013. Urbanism, place and culture in the Malay world: The politics of domain from pre-colonial to post colonial era. City, Cult. Soc. 4, 217-227. doi: 10.1016/j.ccs.2013.05.004

Yeboah, I., 2006. Subaltern strategies and development practice: Urban water privatisation in Ghana The Geographical Journal, 172 (1), 50-65 